\title{
Law Enforcement by the Notary Supervisory Board for Violations toward Law on Notary Position (in Padang City)
}

\author{
Putri Annisa Aulia; Yuliandri; Azmi Fendri \\ Faculty of Law, Andalas University, Padang, Indonesia
}

http://dx.doi.org/10.18415/ijmmu.v6i3.885

\begin{abstract}
In living a life, humans realize that they cannot live alone but need other people and try to connect with others; in relation to legal certainty. One of them is carried out by the role of Notary. The role of Notary which is important in helping to create certainty and legal protection for the community is by issuing authentic deeds made before him/ her that serve as perfect evidence. Through the duties and responsibilities of a Notary, it is reasonable that the Notary is also under supervision. The purpose of supervision carried out by the authorities to the Notaries is that in carrying out their duties, the Notaries do not violate their positions. By the existence of Law No. 30 of 2004 concerning Notary Position and its implementing regulations, it clearly stipulates the responsibilities and obligations of the Notary Supervisory Board. Thus, in carrying out their position, Notaries must be guided by existing regulations so that they can carry out their positions properly. The problems in this study are about how the examination process carried out by the Notary Supervisory Board against the Notary who violated the Law on Notary Position and how the decision-making process by the Regional Supervisory Board in conducting an examination to the Notary. This paper applies the juridical empirical method by reviewing primary and secondary data which are analyzed qualitatively. To strengthen the results of the study, interviews with relevant parties in the research setting were held. Based on the results of the study, it is concluded that in conducting an examination of their profession colleagues who are involved in a case, Notary must have a high sense of integrity in which they must first override friendships in conducting the examination. In the examination of the Supervisory Board, parties from Notary elements also sometimes disagree with two other elements; i.e. the Supervisory Board from the Government and Academics. To achieve collective and collegial decisions, the three elements must equalize their perceptions or views so that collective decisions are made since there is no voting in decision making. This is carried out to avoid the defense action for colleagues which is carried out by the Supervisory Board from the Notary element.
\end{abstract}

Keywords: Law Enforcement; Notary Supervisory Board; Law on Notary Position

\section{Introduction}

Notary institutions have been known in the State of Indonesia since the Dutch colonized Indonesia because it was an institution that had been known in the lives of Dutch people in their own homeland. The existence of Notary institutions appeared in the State of Indonesia to realize legal certainty 
and protection for community members. In the area of private (civil) law, the state places a Notary as the authorized official in terms of making authentic deeds for the purpose of proof or evidence.

The appearance of a Notary institution is based on the need for a binding evidence other than witness evidence. Notary institutions are one of the institutions in Indonesia. This institution arises from the needs in the association of fellow human beings who want the existence of an instrument of evidence regarding the relationship between civil law that exists and or occurs between them. ${ }^{1}$

Notary is a legal profession; thus, the profession of Notary is a noble profession (officium nobile). It is referred to as the officium nobile because the Notary's professional relationship is very close to humanity. Deed made by a Notary can be a legal basis for the status of property, rights and obligations of a person. Errors in the Notary deed can cause the revocation of one's rights or the burden of someone for an obligation. ${ }^{2}$

The function and role of the Notary in the increasingly complex movement of national development is increasingly widespread and developing at this time, because the smoothness and legal certainty carried out by all parties are increasing and broad. This is surely inseparable from the services and legal products produced by the Notary. The government and the wider community certainly have hope that the services provided by Notaries really have values and weights that can be accounted for.

Notaries have a role in carrying out the legal profession that cannot be separated from fundamental problems related to the function and role of the law itself in which the law is interpreted as the rules governing all people's lives. Notary responsibilities relating to the legal profession are inseparable from the opinion that the implementation of their positions is inseparable from the majesty of the law itself. Therefore, the Notary is expected to reflect it in their service to the community.

Since the presence of Notary institutions in Indonesia, supervision of Notaries is carried out by judicial institutions and the government. The purpose of the supervision is so that the Notaries fulfill all the requirements relating to the implementation of the duties of the Notary Position to secure the interests of the community. It is because a Notary is appointed by the Government not for the benefit of the Notary themselves but for the interests of the people they serve. ${ }^{3}$

In addition, to prevent violations committed by a Notary in the form of intentions or negligence, there must be guidance for Notaries. In this case, the roles and functions of the Notary Supervisory Board are needed and expected. The presence of this Notary Supervisory Board can reduce and eliminate legal cases involving errors and violations by Notaries.

Supervision of Notaries is the implementation of the function of guidance and supervision of the implementation of positions and behavior of Notaries. The task was carried out by the Notary Supervisory Board as an extension of the Minister of Law and Human Rights of the Republic of Indonesia who has supervisory authority over the Notary.

On the contrary, the Notary Supervisory Board can also provide sanctions if a position violation conducted by a Notary occurs, which is reported by certain parties to the Supervisory Board. In this case, there are also several Notaries who are involved in criminal law issues in carrying out their position as Notary. The imposition of sanctions is inseparable from the attitude and role of the Notary Supervisory Board at every level in making decisions.

Then there is a mechanism for conducting checks on Notaries suspected of committing violations as stipulated in Law on Notary Position; i.e. by examining the point of view of the Notary Position. Professionalism from the Supervisory Board from the Notary element is required to address the existing problems because those who better understand the world of Notary whether the error is a Notary's mistake or not. The mechanism is intended so that not all cases of alleged violations involving Notaries can be processed according to the law. Therefore, in carrying out the profession in providing legal

\footnotetext{
${ }_{1}^{1}$ G.H.S. Lumban Tobing, Regulations for Notary Position, (Jakarta: Erlangga, 1999). page 2

2 Abdul Ghofur Anshori, Indonesian Notary Society: Legal and Ethical Perspective. Yogyakarta: UII Press, 2009 , page 7.

${ }^{3}$ G.H.S. Lumban Tobing, Regulations for Notary Position, Erlangga, Jakarta, 1983, page 301.
} 
services to the public, notaries need to get legal protection and guarantees in order to achieve legal certainty.

The Notary Supervisory Board not only supervises and examines Notaries, but also has the authority to impose certain sanctions on Notaries who have been proven to have committed violations in carrying out the duties of the Notary. The Notary Supervisory Board is the only agency authorized to supervise, examine and impose sanctions on Notaries who violate their duties. ${ }^{4}$

\section{Research Method}

The method used in this study is an empirical juridical approach; i.e. the way or procedure to solve research problems by examining secondary data first then proceed by conducting research on primary data in the field.

The juridical approach is used to analyze various regulations concerning Notaries. Meanwhile, the empirical approach is used to see positive legal aspects in the application or practice in the field. The method of empirical legal research is a legal research method that serves to see the law in the real sense and examine how the law works in the community. The data used are primary legal materials, secondary legal materials and tertiary legal materials. In addition, this study uses library research and document study as data collection techniques.

In this article, the data processing was carried out through editing and coding. Editing is the process of re-researching the records, files, information collected by data seekers that are expected to improve the quality of reliability of the data to be analyzed. After the editing stage has been completed, the next is coding; i.e. the process to clarify the answers of the respondents according to the criteria or types that have been set (Bambang Sunggono, 2010: 126). It uses qualitative data analysis; the description of the data is analyzed based on laws and regulations and the opinions of experts are then presented with sentences that have previously been analyzed, interpreted and conclusions drawn in accordance with the issues discussed.

\section{Research Results and Discussion}

1. The Examination Process Conducted by the Notary Supervisory Board Against Notaries Who Violated the Law on Notary Position

The Notary Regional Supervisory Board is one of the institutions formed by the Ministry of Law and Human Rights of the Republic of Indonesia to supervise and guide Notaries. This supervision relates to prohibitions and obligations that may not be violated by a Notary; i.e. concerning Law on Notary Position and the Code of Ethics. The Code of Ethics itself comes from Latin, codex, which means association. It is interpreted in Indonesian as a collection of rules from, by and for a group of people working in a particular field. The code of ethics breaks down the rules of basic rules of conduct which are deemed necessary for members of the profession so that they carry out their profession honestly and maintain public trust. In carrying out their duties, a Notary is required to always be guided by applicable laws and regulations in Indonesia. Notaries are also obliged to carry out their duties in accordance with ethics agreed upon in the Notary Code of Ethics. ${ }^{5}$

In conducting an examination of the Notary, the Chairperson of the Notary Supervisory Board forms the Regional Examination Board, the Territorial Examination Board, and the Central Examination Board from each element consisting of 1 (one) chairperson and 2 (two) members of the Examination Board. The Territorial Examination Board and the Central Examination Board have the authority to examine and decide on the reports they receive. The Examination Board is assisted by one secretary. The formation of the Examination Board is conducted no later than 5 (five) days after the report is received. The Examining Board shall refuse to examine Notaries who have marital relations or blood relations in a

\footnotetext{
${ }^{4}$ Ibid, page 11

${ }^{5}$ Ira Koesoemawati and Yunirman Rijan, To Notary, Reach the Success Hope, Jakarta 2009, page 49.
} 
straight up or down line without limitation of degrees, and a straight-to-side line up to the third degree with a Notary. If the member of the Examination Board has such a relationship, the Chairperson of the Notary Supervisory Board must appoint a replacement. ${ }^{6,7}$

In the case of filing a report, the report can be submitted by the party who feels disadvantaged by the actions of the Notary. Reports must be submitted in writing in the Indonesian language accompanied by evidence that can be accounted for. Reports of alleged violations of the Notary Code of Ethics or violations of the implementation of positions can be submitted to the Regional Supervisory Board. The community report is submitted to the Territorial Supervisory Board. In the case of a report submitted to the Territorial Supervisory Board, the Territorial Supervisory Board forwarded it to the Regional Supervisory Board in charge. If the report has been submitted to the Central Supervisory Board, the Central Supervisory Board will forward it to the authorized Regional Supervisory Board.

In the case of summoning a Notary, the Chairperson of the Examination Board shall summon the reporter and the reported party. The summon is made no later than 5 (five) working days before the trial. In urgent circumstances, summons can be made through facsimile which is immediately followed by a summons. If the reporter has been summoned legally and properly but he is not present, a second summon will be made. If the reported party has been called legally and appropriately for the second time but he remains absent, the examination is carried out and the verdict is pronounced without the presence of the reported party. If the reporter has been summoned legally and appropriately but he is not present, the second summon is made. If the reporter remains absent, the Examination Board declares that the report he submitted is null and cannot be submitted again. Examination by the Regional Examination Board is closed to the public. The examination begins within a period of no later than 7 (seven) calendar days after the report is received. The Regional Examination Board must have completed the examination and submitted the results of the examination within a period of no later than 30 (thirty) calendar days from the date the report was received.

The results of the examination are set forth in the deed of examination signed by the chairman and secretary. The delivery letter for the examination report sent to the Territorial Supervisory Board is sent to the reporter, the reported party, the Central Supervisory Board, and the Regional Administrators of the Indonesian Notary Association. At the first meeting that has been determined, the reporter and the reported party are present. Then, the Regional Examination Board conducted an examination by reading the report and hearing the reporter's statement. In the examination, the reported party was given sufficient opportunity to submit a response. Reporters and the reported parties can submit evidence to support their arguments. The report shall be examined by the Regional Examination Board within a period of no later than 30 (thirty) calendar days from the date the report is received.

The examination by the Territorial Examination Board is closed to the public. Decisions are pronounced in hearings which are open to the public. In the event of disagreements among fellow Territorial Examiners, the difference of opinion is contained in the decision. The Territorial Examination Board examines and decides the results of examinations by the Regional Examination Board. The Territorial Examination Board began examining the results of the Regional Supervisory Board's examination within a period of no later than 7 (seven) calendar days since the file was received. The Territorial Examination Board has the authority to call the reporter and the reported party to hear his/her statement. Decisions are stated within a period of 30 (thirty) calendar days at the latest since the file is received. Decisions must contain sufficient reasons and considerations, which are the basis for making decisions. Decisions are signed by the Chairperson, Members, and Secretary of the Territorial Inspectorate. In the event that the report cannot be proven, the Territorial Examining Board shall pronounce a decision stating that the report has been rejected and the reported party has been rehabilitated. In the event that the report can be proven, the reported party is sanctioned according to the level of violation he/ she committed. A copy of the decision of the Territorial Examination Board is submitted to the Minister, the reporter, the reported party, the Regional Supervisory Board, and the

\footnotetext{
${ }^{6}$ Interview with Bu Desmawita, SH, MH, member of the Notary Regional Supervisory Board from the Government Elements in Padang City, on June 10, 2018.

${ }^{7}$ R. Subekti, 2008, Legal Agreement, Intermasa, Jakarta, page 35.
} 
Central Executive Board of the Indonesian Notary Association, within a period of no later than 30 (thirty) calendar days from the pronouncement.

Examination and reading of decisions by the Central Supervisory Board is conducted in a hearing that is open to the public. In the event of differences of opinion among the Central Examination Board, the difference of opinion is contained in the decision. The Central Examination Board checks the appeal for the decision of the Territorial Examination Board. The Central Examination Board begins to examine the appeal file within a period of no later than 7 (seven) calendar days since the file was received. The Central Examination Board has the authority to summon the reporter and the reported party to conduct an examination to hear their statements. The decision is stated within a period of no later than 30 (thirty) calendar days after the file is received. Decisions must contain sufficient reasons and considerations, which are the basis for making decisions. Decisions are signed by the Chairperson, Members and Secretary of the Central Examination Board.

The decision of the Central Examination Board is submitted to the Minister, and the copy is submitted to the reporter, the reported party, the Regional Supervisory Board, the Territorial Supervisory Board, the Executive Board of the Indonesian Notary Association within a maximum of 30 (thirty) calendar days from the statement of the decision.

If the argument submitted to the memory of the appeal is deemed reasonable by the Central Examination Board, then the decision of the Territorial Supervisory Board is canceled. If the argument submitted to the memory of the appeal is deemed unreasonable by the Central Examination Board, then the decision of the Territorial Supervisory Board is strengthened. The Central Examination Board can make its own decisions based on wisdom and justice. If the Territorial Examination Board and the Central Examination Board decide that the reported party is proven to have violated this Law, the reported party will be subject to sanctions in the form of:
a. verbal reprimand;
b. written reprimand;
c. temporary dismissal;
d.respectful dismissal; or
e. disrespectful dismissal.

In the event that the Notary Examination Board finds allegations of criminal elements committed by the reported party, the Examination Board shall notify the Notary Supervisory Board. Allegations of criminal elements notified to the Notary Supervisory Board must be reported to the competent authority for legal remedies for the decision of the Territorial Examination Board. The reporting party and/ or the reported party who object to the decision of the Territorial Examination Board has the right to submit an appeal to the Central Supervisory Board. The appeal law is stated in a period of no later than 7 (seven) calendar days from the date the decision is pronounced. In the event that the reporter and/ or the reported party is not present at the time the decision is pronounced, the reporter and/ or the reported party can declare an appeal within a period of no later than 7 (seven) calendar days from the decision received. Comparator must submit memory appeal. Submission of appeal memory shall be submitted within a period of no later than 14 (fourteen) calendar days from the date the appeal is declared. The appeal memory must be submitted to the comparison within a period of no later than 7 (seven) calendar days from then received by the Territorial Supervisory Board Secretariat. Comparator may submit counter appeal memory within a period of no later than 14 (fourteen) calendar days as of the appeal memory received by the comparison. The appeal memory and counter appeal memory were submitted by the Secretary of the Central Examination Board through express mail addressed to the comparator and comparison. In the event that the comparison does not convey the appeal memory within the stipulated period, the appeal statement cannot be accepted and will be decided by the Central Examination Board. The Central Examination Board can strengthen, amend, or cancel the decisions of the Territorial 
Examination Board, and decide for themselves. The decision of the Central Examination Board is final and has permanent legal force, except the decision regarding the submission of sanctions in the form of dismissal with no respect for the Minister. Decisions regarding the submission of sanctions in the form of disrespectful dismissal to the Minister which shall be submitted by the Central Supervisory Board within a period of no later than 30 (thirty) calendar days from the pronouncement of the decision. The Decision of the Central Examination Board whose ruling provides sanctions in the form of disrespectful dismissal, must be submitted to the Minister. The Minister gives a decision on the proposal of giving sanctions of disrespectful dismissal within a period of 30 (thirty) calendar days from the date the proposal is received. The Minister's decision is submitted to the reporter, the reported party, the Central Supervisory Board, the Territorial Supervisory Board, the Regional Supervisory Board, and the Central Executive Board of the Indonesian Notary Association. The procedure for making decisions in a trial is through collective decisions between the Supervisory Board from the Government, Notary and Academic elements.

\section{Decision Making Process by the Regional Supervisory Board on Notary Examination}

In a trial, dissent became commonplace. In the trial, there are three elements that are different from each other. That will certainly lead to dissenting opinions; i.e. differences of opinion between the three different elements.

In conducting an examination of a Notary who violates the Law on Notary Position, there is a special institution that handles it; i.e. the Notary Supervisory Board. In this institution, there are three different elements in conducting an examination of a Notary: Elements of Government, Elements of Academics and Elements of a Notary. In conducting a hearing against Notaries, the elements of the Notary will be more inclined to issue opinions that retain their professions.

The Notary element who is in the element of the Supervisory Board's membership is not intended to defend their profession; in the sense of defending "person" but defending the dignity of the Notary position as "officium nobille". The reason is that if there are many Notaries who stumble over the problem, the image of a Notary will be bad in the eyes of the community simply because a handful of Notaries make mistakes in carrying out their positions.

In the event of differences of opinion between members of the Notary Supervisory Board who come from the Academic, Government and Notary elements, then the three elements must equalize each other's perceptions or views in order to produce collective decisions or joint decisions. There is no voting or most voting in decision making. It only equates the opinions of each element consisting of Government, Academic and Notary elements. Equating opinions here means that the elements of the Notary know more about the world of notary while the elements from the Government and Academic elements do not know it. So, each element balances the results of each other's thoughts. The Notary element must have a high sense of integrity in conducting an examination of their profession. Notary elements must override friendships with the Notary being examined. Notary elements can express opinions that can keep their colleagues in court.

The results of the study show that differences of opinion in the trial have not been found. Some of the influencing factors are the least amount of dissent in decision making. Another factor is that there is a strong cultural tolerance for other people's opinions. Provisions for differences of opinion are regulated in Article 28 of Law No. 2 of 2014 concerning Amendment to Law No. 30 of 2004 which states as follows:

\section{Article 28}

a. Examinations and readings of decisions are carried out in hearings that are open to the public

b. If differences of opinion among Examination Board occur, the differences of opinion are included in the decision. 


\section{First Case: Notary AR in Padang City}

Based on the results of the examination in the Padang Regional Supervisory Board session on November 27, 2018, the following legal facts were found:

a. E, as the reporter, sent a letter to the Padang Regional Supervisory Board in connection with the problems she experienced regarding the name of the certificate.

b. Based on this, the Padang Regional Supervisory Board, in accordance with Article 70 letter a of Law No. 30 of 2004 which has been amended into Law No. 2 of 2014 concerning Notary Position, has the authority: to hold a hearing to examine the alleged violation of the Notary Position Implementation or the Notary Code of Ethics. Therefore, the Padang Regional Supervisory Board formed the Examination Board to examine suspected violations of the Notary Position conducted by the Notary AR.

c. The hearing was held on Tuesday, November 27, 2018 by presenting E as a reporter and Notary $\mathrm{AR}$ as the reported party.

d. Based on the reporter's information, the following information is obtained:

1) The reporter has a debt to a Regional Bank with a house certificate as the collateral.

2) At that time, the reporter had been in arrears for several months because the reporter was hospitalized, and at that time the reporter was visited by a member of the Notary to ask for a signature.

3) After being discharged from the hospital, 3 months later, the reporter's brother stated that the house would be auctioned due to arrears to the Bank.

4) Based on this, the reporter is brought by his brother to the Bank to settle the debt.

5) After arriving at the Bank, the reporter is invited to leave the Bank to sign a document because the debt has been carried out by the reporter's sister and the reporter's sister asks to take the certificate of the house.

6) After arriving at the house, the sister of the reporter requested a signature from the reporter's brother.

7) The reporter then learned that the certificate's title had been transferred before Notary AR.

8) The reporter stated that the reporter had lost in court.

9) At this time, the original house certificate was held by the reporter's sister.

10) Based on information from the reported Notary AR, the reported party admitted that the signing was not carried out before the person concerned because the person concerned could not be present at that time. Therefore, the signing was carried out outside the Notary's office and in the presence of members of the Notary AR.

Based on the results of the interview with Mrs. Desmawita (member of the Regional Supervisory Board) in Padang, the impact of the number of Notaries that increased each year could lead to unfair competition. Notaries who behave well and carry out their professional duties become excluded as new Notaries emerge who often violate the law. In the case of a Notary, the parties in making a deed do not signed before the Notary at once. It also often happens that the Notary does not read the deed in front of them. However, there is little chance that a case will be known or reported and acted upon.

The practice of such a Notary actually does not only violate his/ her oath but can even be categorized as a Notary in good faith and deliberately wants to make a fake deed, which leads to a 
criminal act and can be brought to court. However, in reality it is difficult to do because generally people who need Notary services do not know and do not care about these practices.

Referring to Article 16 and 17 Law on Notary Position, a Notary should act honestly, thoroughly, independently, impartially and protect the interests of the parties involved in law making. Therefore, the Notary AR's actions have resulted in losses. Following the opinion of R. Subekti, the existence of signatures from the appearers generally required the making of deeds such as reading the signing, giving copies, and filing for the original deed.

In a Notary deed, this indicates that the viewers have agreed to what was agreed or agreed upon by both parties; namely the appearers themselves. Signing must mean seeing (reading) and agreeing to what is written. In carrying out office duties, the Notary must comply with the Law on Notary Position and the Notary Code of Ethics, Law No. 30 of 2004 concerning Position of Notary which is a substitute for Notary Reglement Staatsblad 1860 No. 3 Notary Position Regulations containing contents of material law and formal law. Material law concern on provisions relating to the position and function of a Notary, as in Article 1; as well as supervision of the Notary and what he/ she made. Formal law is no less important; for example, as an authentic proofing tool, it must fulfill all the necessary provisions so that a notary deed has a legal form. If the provisions are not fulfilled, it will eliminate the authentic nature.

In connection with the deed made by a Notary, the signing of a deed must be carried out in accordance with the place or position and territorial work of the Notary, in accordance with Article 18 paragraph (1) and (2) Law on Notary Position which states that: "The notary has a place of domicile in the area regencies or cities, and Notaries have territorial positions covering the entire territory of the province from their place of residence".

The reading of the Deed has meaning and purpose in the presence of the viewers. The reading of the Notary Deed is an obligation where the reading of the Deed is carried out before the viewer in the presence of witnesses, totaling at least 2 (two) people. This reading is not required to the Notary when the appearer has read it himself and received an explanation from the Notary and knows the contents of the deed, with special conditions that on every original deed page, the Deed must affix the appearance of the appearers, witnesses and Notaries. Readings made by a Notary or read by the appearers themselves, aiming for the appearers who sign the Deed to understand the contents of the Deed so that the Notary Deed actually makes a will or in accordance with the wishes of those who sign it. The above provisions mean that the reading of the Deed as referred to in Article 16 paragraph (1) the revised letter $\mathrm{m}$ Law on Notary Position is not required if it is desired by the appearers. Thus, the Deed is not read because the appearers have read it themselves, known, and understood its contents, provided that this is stated in the closing of the Deed (end of Deed). In addition, each Original Deed page is signed by appearers, witnesses and Notaries.

The obligation of the Notary to read or not read the Deed must be included in the final part of the Deed. The goal is for each party to know whether or not at the time the deed was made. If that has been read, then, each of the viewers is considered to have known the contents of the Deed.

To carry out the position, a formal Notary should:

a. Make an introduction to the appearers based on the identity they show to the Notary.

b. Asking and observing the will of the parties.

c. Check the proof of the letter relating to the wishes of the parties.

d. Give advice and make original deed to fulfill the wishes of the parties.

e. Meet all administrative techniques for making deeds such as reading, signing, giving copies and filing for original deed.

f. Perform other obligations relating to the implementation of the position of notary.

g. Providing services in accordance with the provisions of Law on Notary Position, unless there is a reason to reject them. 
Notaries must also see the identity of the appearers whether they represent themselves personally or represent certain bodies or institutions. In the context of law enforcement, in addition to regulations that further guarantee legal certainty, it requires guidance and supervision of Notaries by carrying out checks on public reports so that the examination by the Notary Regional Supervisory Board can continue even though the authority to impose sanctions is still in the Notary Central Supervisory Board and Territorial Supervisory Board.

The following are the factors that trigger the violations committed by the Notary and the solution.

Table 1. Factors that Trigger the Violations Committed by the Notary and the Solution.

\begin{tabular}{|l|l|l|}
\hline No. & Trigger Factors of Violations & The Solutions \\
\hline 1. & Regulation of Notary Affairs & $\begin{array}{l}\text { It requires reformation of notary regulations so that Law on Notary } \\
\text { Position and the Code of Ethics are more effective towards legal certainty. }\end{array}$ \\
\hline 2. & The role of the organization & It requires revitalization of the organization. \\
\hline 3. & Supervision & $\begin{array}{l}\text { It requires continuous supervision with the active role of fostering and } \\
\text { enhancing relevant institutions supported by independent institutions. }\end{array}$ \\
\hline
\end{tabular}

A notary, as a professional who at the same time becomes a public official and serves the interests of the community, should hold fast to the trust that the parties have entrusted to him. Referring to and agreeing with Habieb Adjie, the implementation of the Notary's duty as a trustee's office begins when the prospective Notary promises or takes his/ her oaths based on their respective religion as a Notary. Oaths or promises as a Notary contain very deep meanings that must be carried out and are binding upon carrying out their duties as a Notary. The oath or promise contains two things that must be understood: Notaries must be accountable to God, because the oath or promise is stated based on their respective religions. It means that everything that a Notary does in carrying out his/ her duties will be held accountable in the form desired by God. In addition, the Notary must be accountable to the State and the community. In this case, the State has given them the confidence to carry out state duties in the field of civil law; i.e. in the manufacture of evidence in the form of deeds that have the power of perfect proof and to the community who have believed that the Notary is able to formulate their will in the form of a Notary deed and believed that the Notary is able to keep all statements or information given before a Notary. The Padang Regional Supervisory Board has attempted to inventory the Notary profession's deviations from other more complex forms of violations such as the Notary AR's case.

\section{Conclusions}

Based on the description of the above chapters regarding law enforcement by the Notary Supervisory Board against violations of the Law on Notary Position, the following conclusions can be drawn and explained:

1. In conducting an examination of a Notary who violated the Law on Notary Position, there is a special institution called the Notary Supervisory Board. This institution consists of three different elements to conduct an examination of a Notary; i.e. Government Element, Academic Element and Notary Element. In conducting a hearing against a Notary, the Notary element will be more inclined to issue an opinion that maintains their profession.

2. The examination process carried out by the Notary Supervisory Board is carried out due to reports from the public who felt that they were harmed by the Notary's actions that violated Law on Notary Position. Examination from members of the Supervisory Board from the Notary element tend to have opinions that more sustain their professions. However, during the examination process, the friendship must still be ruled out in order not to cause an element of bias in the examination process. The notary who is involved in the problem, in this case, will be examined first by the Regional Supervisory Board. After the examination, if there is a severe violation, the Regional Supervisory Board recommends that the examination process be continued by the Territorial Supervisory Board because the Regional Supervisory Board does not have the authority to impose sanctions on Violations of Law on Notary Position conducted by 
Notaries. The party authorized to sanction is the Territorial Supervisory Board and the Central Supervisory Board. The Regional Supervisory Board is only authorized to examine Notaries because of reports from the public. A notary who is proven to have committed a violation of the execution of his/ her position will be sanctioned by the Territorial Supervisory Board in accordance with the level of the violation committed by the Notary concerned.

3. In a trial, dissent became commonplace. In the trial, the existence of three different elements from each other will certainly lead to dissenting opinions; i.e. differences of opinion between the three different elements. If differences of opinion between members of the Notary Supervisory Board originating from the elements of Academics, Government and Notary elements occur, the three elements must equalize each other's perceptions or views in order to produce collective decisions or joint decisions. There is no voting or the most votes in decision making, it only equates the opinions of each element consisting of elements of the Government, Academic and Notary elements. Equating opinions here means that the elements of the Notary know more about the world of notary while the elements from the Government and Academic elements do not know it; thus, each element balances the results of each other's thoughts. Elements of a Notary must have a high sense of integrity in conducting an examination of their profession. Notary elements must override friendships with the notary being examined.

4. There are not many differences in opinion in the trial. Some of the influencing factors are the least amount of dissent in decision making. Another factor is a culture of tolerance for the opinions of others who are still strongly attached. Differences of opinion are regulated in Article 28 of Law No. 2 of 2014 concerning Amendments to Law No. 30 of 2004.

\section{Suggestions}

1. In conducting guidance and supervision, the Notary Supervisory Board must be responsive in handling violations committed by Notaries and in handling every violation case that occurs so that their authority and capability are maintained in the eyes of the public. The existence of the Notary Supervisory Board should not create an impression as an institution that is in favor of the Notary. The Notary Supervisory Board must be serious in becoming an independent institution in carrying out the tasks of guidance and supervision to the Notary.

2. It is suggested to prioritize the views between the relevant parties, especially fellow members of the Notary Supervisory Board, so that the differences in elements (the government, Notary and academics elements) in the Notary Supervisory Board membership did not create obstacles in carrying out the duties and authority of the Supervisory Board.

3. In carrying out the examination process against Notaries, members of the Supervisory Board from the Notary element must have high integrity. If he/ she has a friendship with the Notary being examined, the Notary who is a member of the Supervisory Board must first override his/ her friendship with the Notary being examined.

\section{References}

Books

Abdul Ghofur Anshori, Indonesian Notary Society: Legal and Ethical Perspective. Yogyakarta: UII Press, 2009, page 7.

G.H.S. Lumban Tobing, Regulations for Notary Position, (Jakarta: Erlangga, (1999). page 2.

G.H.S. Lumban Tobing, Regulations for Notary Position, Erlangga, Jakarta, 1983, page 301.

Ira Koesoemawati and Yunirman Rijan, To Notary, Reach the Success Hope, Jakarta 2009, page 49. 
R. Subekti, 2008, Legal Agreement, Intermasa, Jakarta, page 35.

Law/ Legislation

Law of the Republic of Indonesia No. 2 of 2014 concerning Amendment to Law No. 30 of 2004 concerning Notary Position.

Presidential Decree No. 21 of 2004 concerning the Transfer of Organizational, Administrative and Financial Affairs in the General Courts and State Administrative Courts and Religious Courts to the Supreme Court.

Regulation of the Minister of Law and Human Rights of the Republic of Indonesia No. 40 of 2015 concerning Procedures for Appointment of Members, Dismissal of Members, Organizational Structure, Work Procedures, and Procedures for Examining the Notary Supervisory Board.

\section{Copyrights}

Copyright for this article is retained by the author(s), with first publication rights granted to the journal. This is an open-access article distributed under the terms and conditions of the Creative Commons Attribution license (http://creativecommons.org/licenses/by/4.0/). 